\title{
Rampes: counselor characteristics in Sanghyang Siksakandang Karesian manuscript
}

\author{
Ade Hidayat $^{{ }^{*}}$, Sunaryo Kartadinata ${ }^{2}$, Mamat Supriatna ${ }^{2}$, Peni Ramanda ${ }^{1}$ \\ ${ }^{1}$ Universitas Mathla' ul Anwar Banten, ${ }^{2}$ Universitas Pendidikan Indonesia \\ *Corresponding author, e-mail: adehidayat@unmabanten.ac.id
}

\begin{abstract}
The aim of this study is a description of counselor characters obtained from the values of Sanghyang Siksakandang Karesian (SSK) manuscript. Qualitative approach was used in which the data, analysis, and interpretation conformed to the principles of hermeneutics. As a method, hermeneutics was employed to interpret the text meaning within the SSK. The research procedure comprised selection of texts source, dialogic process involving negotiation and re-negotiation of texts interpretation until the full understanding of the texts was gained, and concept writing. The results suggest that in the SSK, there are three focal aspects supporting the counselors personal quality; that are: 1) religious, submissive and obidient to The Most Supernatural Power of God (Batara Seda Niskala); 2) being wastu siwong, a human being having good attitudes, excel at science, and knowledgable about the value of life; and 3) comprehensive about pangimbuh ning twah, the complementary thing toward the success of life in society. These three aspects in this study form a Rampes counselor.
\end{abstract}

Keywords: Codex, Sundanese, Values.

How to Cite: Hidayat, A., Kartadinata, S., Supriatna, M., Ramanda, P. (2019)Rampes: counselor characteristics in Sanghyang Siksakandang Karesian manuscript. International Journal of Research in Counseling and Education, 3 (1): pp. 33-41. DOI: https://doi.org/10.24036/0070za0002

\section{Introduction}

Guidance and counseling is one of the disciplines that is increasingly needed by society, and is the most important and integral part of education (Dahlan, 1988; Kartadinata, 2011). As part of education as well as a professional service, guidance and counseling activities are carried out normatively (Kartadinata, 2011), constructed and grounded from a solid foundation based on the results of inquiry and in-depth research, so that it can provide substantial benefits for human life, especially for the counselee, with no exception to students, students, practitioners, economists, society, academics, and bureaucracy as well (Lubis, 2012).

Guidance and counseling activities, in essence, are mutual interactions in which there is a mutual relationship between the counselor as the assistant and the counselee as the client. Counselors are assumed as individuals who will guide the counselee in achieving certain value and goals (Williamson, 1958). Then, in this relationship it needs certain capacity that must be owned by them. This capacity determines the quality of the counselors. Such quality comprises all criteria of excellence including: personality, knowledge, insights, skills, and values, which will determine the success (effectiveness) of the guidance and counseling process (Fuad, 2009).

The personal qualities of counselors who concern on the aspects that match with the values of the counselees in Indonesia can be found in the values of local wisdom in many regions. Among them, it is the local wisdom contained in Sanghyang Siksakandang Karesian (SSK) manuscript.

The original SSK manuscript consists of 30 sheets of palm leaves in the collection of the National Library of Indonesia in Jakarta, and is marked by the name of kropak 624 and 630 in the year of nora catur sagara wulan (traditional year naming system meaning 0-4-4-1) or 1440 Saka which coincided with 1518 AD (Danasasmita et al, 1987). The manuscript was first re-written by Atja in 1972, then in 1981 Atja and 
Danasasmita translated it into modern Sundanese and simultaneously with the Indonesian translation (Hamzah 2002).

The SSK manuscript is an ancient one providing an illustration that at the time of this manuscript creation, there had been a living order based on values relating to religious life, morals, public welfare, arts, and so forth. So it may be true that the SSK text is considered as the Encyclopedia of Sundanese (Hamzah, 2002).

The initial information about the manuscript of Sanghyang Siksakandang Karesian (SSK) was first disclosed in the research of Atja and Saleh Danasasmita in 1981. The research was a follow-up from the information published by KF Holle in 1867. Holle announced three Sundanese ancient manuscript (codex) or Naskah Sunda Kuna (NSK) as a giving from Raden Saleh to Bataviaasch Genootschap van Kunsten en Weteschapen (BGKW), that are: the Amanat Galunggung codex (Kropak 632), Candrakirana codex (Kropak 631), and Sanghyang Siksakandang Karesian codex (Kropak 630) (Nurwansah, 2013).

Conveying the values contained in the ancient manuscripts becomes important for the sake of enrichment for educational development in the future. This is in line with what Ki Hadjar Dewantara says: To get a teaching system that will benefit the common life, it must be tailored to life and life of the people (Dewantara, 1977). The statement shows that good education is the one that does not forget the origin of local culture. Education should grow and be directed to the fostering and development of awareness to the environmental or socio-cultural conditions (Harish, 2011). The values contained in ancient manuscript are important to be explored in order to obtain the dynamic and positive values for educational development, so that goal setting or orientation to a dignified and highly civilized nation can be achieved. Orientation is needed as a guide in the realm of rapid and complex life changes (Suseno, 1987).

Realistic studies and perspectives with regard to the local culture and indigenous knowledge or local wisdom ultimately get guidance and counseling scholarship remains exist in the academic arena, while benefiting the society at large. Thus, the study examining the personal qualities of the counselor in Sanghyang Siksakandang Karesian SSK as one of local wisdom gains its significance and relevance for the future development of guidance and counseling scholarship.

\section{Method}

Guidance and Counseling recently starts to develop from examining the micro level (individual, group, and family) to macro level (community) because to be able to understand the counselee $\mathrm{s}$ problem correctly, it is necessary to understand the social, cultural, and political contexts contributing to the problem (Arifin \& Zaini, 2014). Thus, guidance and counseling studies require other scientific disciplines (e.g. theology, philosophy, arts, and other sciences) and are required to be studied by other experts.

Counseling is considered as applied science. Therefore, investigating the local wisdom is very important. Some guidance and counseling experts have offered to give this practice a space for local culture values. One approach to counseling based on Indonesian culture is that from values in ancient manuscripts (codex) spread in the archipelago. One of which is from Sanghyang Siksakandang Karesian (SSK) manuscript.

Efforts to assess the personal characteristics of counselors in the SSK manuscript as one of these local wisdoms use hermeneutical studies under guidance and counseling perspectives. Thus, this study is considered as indigenous guidance and counseling studies. Indigenous guidance and counseling presents an approach in context (family, social, culture, and ecology), and its contents (meaning, value, and belief) are explicitly incorporated into the research design (Kim, Yang, \& Hwang, 2010).

This study concerns mainly on meaning and interpretation of SSK manuscript related with ideal character of counselor. Hermeunetics is qualitative research type that focus on human experience in comprehension pursuit about an object. The hermeunetics is defined as comprehension study, especially comprehension on text (Palmer, 1969).

For understanding some values in SSK manuscript, it needs interpretation device. It then underlies using hermeunetics method as the blade analysis (Palmer, 1969; Hidayat, 2011) to comprehend SSK manuscript. The researcher uses principle of Gadamer Hermenetics as dialogical process that emphasize more on reader (researcher) interaction process with text subject (SSK manuscript).

In this interpretation process, as Gadamer said, interaction occurs between interpreter (researcher) and text. Gadamer called it as dialogical process, it is a perspective that emphasize on interaction process between research and text (Valdes in Rahardjo, 2010). The process forms a cycle that described as part-whole logic. 


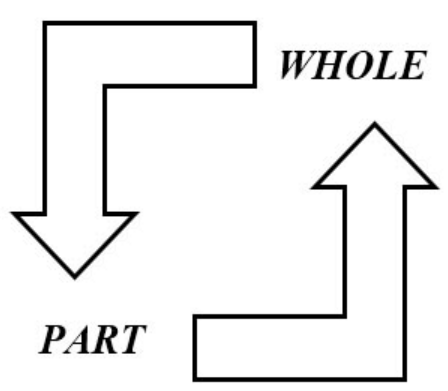

Figure 1. The Hermeneutics Cycle

The Figure 1 describes that the interaction process between (research) and text is the most important thing in Gadamer hermeneutics perspective. But, for research needs, the steps need to be modified in order to be more applicable. Therefore, the researcher applies some steps of data analysis that adopted from Patterson \& Williams (2002) that using code system. The system shape of organizing data is presented in Table 1.

Table 1. The System of Organizing Data

\begin{tabular}{lll}
\hline Original Text & Translation & Code \\
\hline Jaga rang dek luput ing na pancaga/n/ti, & Beware to avoid the pancagatı (five & $5: 1$ \\
sangsara. Mulah carut mulah sarereh, mulah & moral deficiencies) in order not to be & \\
nyangcarutkeun maneh. Kalingana & suffer, don't be treacherous, don't be \\
nyangcarutkeun maneh ma ngaranya: nu & deceitful don't be self-betrayed. Self- \\
aya dipajar hanteu, nu hanteu dipajar waya, & betrayed is saying wrong to correct \\
nu inya dipajar lain, nu lain dipajar inya. & something, saying correst to wrong \\
& something. \\
\hline Description: The code of 5:1 means that data is found on page 5, number 1.
\end{tabular}

The research focuses on text study that describe some features of personality value of counselor that is revealed in SSK manuscript. The text that is studied as the object of research is SSK manuscript which has been translated and booked by some culture expert and Sundanese ancient manuscript. As primer data source, the researcher uses only one book in order for ease in reading SSK manuscript. The book that used is titled: Sewaka Darma (Kropak 408), Sanghyang Siksakandang Karesian (Kropak 630), Amanat Galunggung (Kropak 632): Transkripsi dan Terjemahan that is arranged by Danasasmita, Ayatrohaedi, Wartini, \& Darsa, published in 1987. The book is not the latest, but as far as the findings, there is not newest translation book SSK manuscript yet except the book mentioned above.

The seconder data source that is used in this research consists of some literatures that related with research object and data such as interview result, discussion with some stakeholders that considered have comprehension related the research object.

\section{Results and Discussion}

This research uses experimental method. The study population is the faculty of science education. The sample of the research is guidance and counseling students. The sampling technique uses cluster sampling. The experimental samples were divided into two groups aimed at looking at the consistency of the treatment. Both groups were given counseling guidance treatment by using classical approach contextual teaching and learning (CTL). The number of sample group 1 is 22 students and group 2 is 22 students. The instrument used is RFN reading skill instrument in adaptation of Nurhadi theory (2016). Treatment is given four times during one month. Data analysis using Kolmogorov Smirnov 2 Independent Sampels to see the consistency of treatment effect.

\section{Results}

\section{Understanding of Rampes}

The counselor of Rampes is named by the researcher who find the personal characteristics of a counselor raised and interpreted from the values contained in the SSK manuscript. The word Rampes in the manuscript is mentioned 24 times. This repetition should be interpreted as an important matter needed to be explored in the SSK manuscript. Rampes, commonly expressed as an answer from Sunda greetings; sampurasun. The 
answer is usually accompanied by the saying Mugia Rahayu Sagung Dumadi which means you all . Sampurasun is derived from the phrase sampura ning ingsun which means good answered with Rampes meaning (has) got myself good (Hendrawan, 2013).

good luck to get yourself

Danasasmita et al. (1987) in the translation of the SSK manuscript defines Rampes as perfect, kind, good, and beautiful. Derived from various words, this research defines Rampes as the personal characteristics of the ideal and professional counselor in carrying out his profession. The process of conveying the meanings of Rampes in the SSK manuscript provides an understanding to further explore any aspect in order to form the figure of the Rampes. The results of the research are formulated in the forms of three aspects of Rampes, which comprise: 1) religious aspect, 2) wastu siwong (advice aspect), and 3) pangimbuh ning twah (complementary aspect to avoid life failure).

\section{Submissive and Obidient to God}

The formulation of the first aspect of the personal qualities of the counselor contained in the Sanghyang Siksakandang Karesian SSK is the religious aspect; that is the whole consciousness as God's creature. The manuscript pinpoints the obligation for human beings to worship, serve, be pious to God as shown in Table 2 .

Table 2. Text Containing a Religious Aspect in the SSK Manuscript

\begin{tabular}{|c|c|c|}
\hline Original Text & Translation & Code \\
\hline $\begin{array}{l}\text { Sahinga ning guna kreta kena itu tangtu } \\
\text { Hyang tangtu Dewata }\end{array}$ & $\begin{array}{l}\text { All of them are from Hyang and Dewata } \\
\text { (deities) }\end{array}$ & $20: 4$ \\
\hline $\begin{array}{l}\text { Sakala batara jagat basa ngretakeun bumi } \\
\text { niskala. Basana: Brahma, Wisnu, Isora, } \\
\text { Mahadewa, Siwah. }\end{array}$ & $\begin{array}{l}\text { The voice of time ruler perfecting the } \\
\text { mayapada (the throne of Batara). He said: } \\
\text { Brahma, Wisnu, isora, Mahadewa, Siwah. }\end{array}$ & $20: 5$ \\
\hline $\begin{array}{l}\text { Bakti ka batara! Basana: Indra, Yama, } \\
\text { Baruna, Koera. Besawarma. Bakti ka } \\
\text { batara! Basana: Kusika, Garga, Mestri, } \\
\text { Purusa, Patanjala, bakti ka batara: sing } \\
\text { para dewata kabeh pada bakti ka Batara } \\
\text { Seda Niskala. Pahi manggihkeun si tuhu } \\
\text { lawan preityaksa. }\end{array}$ & $\begin{array}{l}\text { Devote yourselves to Batara (the God)! } \\
\text { He said: Indra, Yama, Baruna, Kowara, } \\
\text { Besawarma, devote yourselves to Batara! } \\
\text { He said: Kusika, Garga, Mestri, Purusa, } \\
\text { Patanjala, devote yourselves to Batara! } \\
\text { So, all of the deities devote themselves to } \\
\text { Batara Seda Niskala. The one capturing } \\
\text { "The Rights" and "The Exist" }\end{array}$ & $21: 1$ \\
\hline
\end{tabular}

The text 20:4, 20:5, and 21:1 calls that God is the highest, most powerful, and single supernatural power. In the Sanghyang Siksakandang Karesian called Batara Seda Niskala (SSK 21:1). The SSK manuscript as the guideline of Sundanese ethics mentions that God is close to human, and always pays attention to human behaviors. If he/she behaves well, the result will also be good. Otherwise, if he/she behaves badly, the result will also be bad (Nurazizah, 2016).

God is the Almighty determinant of everything (20:4). To God, human and other creation have to submit, obey and dedicate to (21:1). Manuscript SSK encourage individual to have religious orientation, it is capability to look every events by religion perspective and guidance from God as Batara Seda Niskala (Ekadjati, 1995). The religious individual is someone who believe and perform worship a power that exists outside of him

Religiosity is almost always related with being created of psychological well-being (Wicaksono \& Meiyanto, 2003, p. 59). Spink (1963) said that every single individual has an instinct or desire called religious instinct. It is a desire that encourage an individual to perform religious act.

Religious individuals tend to have peace and tranquility (Zainuri, 2010). Carl Gustaf Jung mentions that any psychiatric illness is associated with religious factors (Darajat 1993). Nevertheless, before Western scholars perceived positively on religion, antagonism between religion and psychology had long existed (Lovinger, 1984). Freud calls religion as a universal neurosis (Meyer 1988) or as an enemy (Lannert 1991). The psychologists of the last century have expressed two reactions: being neutral toward religion like Rogers or being hostile like Albert Ellis (Quackenbos, Privette, \& Klentz, 1986). Albert Ellis calls religion as an emotional disturbance (Quackenbos, Privette, \& Klentz, 1986). Although there are indications that religion may be a factor of depression (Cadwallader, 1991), religious allegations of mental illness are not supported by empirical research (Bergin 1989). In fact, on the contrary, religion and spirituality can have a positive effect on a person (Worthington, Kurusu, McCollough, \& Sandage, 1996). Thus, the development of modern 
psychology studies, religious studies, and spiritual phenomena becomes an important and positive study (Lines, 2006; Nickles, 2011; Miller \& Ewest, 2013; Hidayat, 2016; Novitasari \& Nur, 2017; Novitasari, 2017).

Incorporating religion in the counselor education programs is important. The counselor is not only aware of his/her own religious dimension, but he/she will develop a state of respect for the diversity of the counselees religious beliefs (Naqiyah, 2011). It is in line with Pate Jr. \& Brodi (1992) who propose a counselor education programs by incorporating religious teaching. The religious values included in the programs will strengthen the point of cultural awareness, and are important to all counseling situations. Incorporating the components of religious values will also enable the information identification about how far religion affects the counselees.

Another focal thing is the consciousness as a religious person in which a full belief as God's creature is needed; belief that will lead to the spirit of dedication and sincerity to help the counselees as God s creature as well. The altruistic spirit leads to the amar ma'ruf (do good things or doings) and the l'esprit de corpse preserving the noble profession or nahi munkar (avoid bad things or doings) against the irregularities that potentially degrade the profession.

\section{Being Good Attitudes}

The second personal characteristics of the counselor can be seen from the concept of deeds and sins or right and wrong as two sides that are always attached to humans. Raised from the concept, in the SSK manuscript, humans behaviors are divided into three types: 1 ) janma wong (physically human, but close to the janja triyak (animal creature) because of bad behaviors; 2) janma siwong (good character, but not yet perfect for not mastering the sanghyang darma (knowledge); and 3) wastu siwong (good in behavior, proficient in knowledge, and skillful in the nature of life) as shown in the Table 3.

Table 3. Text Containing a Good Attitudes Aspect in the SSK Manuscript

\begin{tabular}{llc}
\hline Original Text & Translation & Code \\
\hline Janma wong ma ngara(n)na: ruana janma & Janma wong is: the physical appearance is & $27: 5$ \\
kena ten hade yunina, Janma siwong ma. & indeed human, but the behaviors are bad. & \\
ngara(n)na: rampes yuni rampes bangsa & Janma siwong is: the behaviors are good, \\
kena acan nyaho di sanghyang darma. & but the sanghyang darma (knowledge) is \\
$\begin{array}{ll}\text { Wastu siwong ma ngara(n)na: nu teguh } \\
\text { kanyaho, nyaho sanghyang darma, nyaho }\end{array}$ & limited. Wastu siwong is: the knowledge is \\
jero sanghyang ajnyana, ya wastu siwong & the value of knowhyang ajnyana (searching \\
ma ngara(n)na. & wastu siwong \\
\hline
\end{tabular}

Based on the division of human characters or characteristics based on the SSK 27:5 quote, then ideally and normatively, the counselor conforms to the level of wastu siwong. Wastu siwong is a combination of knowledge, skills, characters, motives, and self-conception. Individuals who have had wastu siwong are competent, have intellectual capital, able to work professionally, able to provide consultation, and able to provide advice for individuals who need guidance.

The intellectual capital of the counselor becomes crucial in supporting the qualification of a professional (Ulrich, 1998). Counselor as one of the professional activities must be supported by strong intellectual capital. Sofyan S. Willis (2009) describes the qualifications of a counselor are all of the criteria to excellence including personality, knowledge, insight, skills, and values that will facilitate the person in carrying out the counseling process to achieve the goal successfully (effectively). Cavanagh (1982) mentions the aspect of competence is the quality of physical, intellectual, emotional, social, and moral capacities. Then, another important one is the cultural intelligence first introduced by Early and Soon Ang in 2003 (Latif, 2017).

Over the last decade, the issue of cultural awareness has implications to paradigmatic changes in the counseling dimension (Sanyata, 2006). In various approaches, cultural issues are incorporated to new awareness in establishing counseling interactions. Corey (2005) argues that multicultural counseling has three dimensions of competence: (1) beliefs and attitudes, (2) knowledge, and (3) intervention skills and strategies. The beliefs and attitudes of the counselor concern on the issue of personal bias, values and problems to be faced, and the ability to work in different cultures, while the knowledge factor concerns on the ability to build personal communication professionally to provide services to the counselees with an understanding of diverse cultural backgrounds. Another important competence is the skill to use methods and strategies in explaining the purpose of counseling consistently considering the background of varied cultural perspectives. 


\section{The Complementary Thing Toward The Success of Life in Society}

The third formulation of the personal qualities of a counselor is the understanding of the concept of pangimbuh ning twah, or complementary competence in order not to fail in family and community life (Sumarsono, 2013), which is asserted in the Table 4.

Table 4. Text Containing a Pangimbuh Ning Twah Aspect in the SSK Manuscript

\begin{tabular}{lll}
\hline Original Text & Translation & Code \\
\hline Ini pangimbuh ning twah pakeun mo tiwas & It is a complementary behavior in order not & $13: 3$ \\
kala manghurip, pakeun wastu di imah di & to fail in life; to get the household blessed; & \\
maneh. Emet, imeut. rajeun, leukeun, & that is being careful, thorough, diligent, \\
pakapradana, morogol-rogol, purusa ning sa, & determined, confident, enthusiastic, \\
$\begin{array}{l}\text { widagda, hapitan. karawaleya, cangcingan, } \\
\text { langsitan. Jaga rang ngajadikeun gaga-sawh, }\end{array}$ & patriotic, wise, brave, generous, tenacious, \\
$\begin{array}{l}\text { tihap ulah sangsara. Jaga rang nyieun } \\
\text { kebo/a/n, tihap mulah ngu(n)deur ka huma }\end{array}$ & miserable life. We make a yard to get to ask \\
beet sakalih, ka huma lega sakalih. Hamo ma & for vegetables from other people because of \\
beunang urang laku sadu. Cocooan ulah & inaffordability to do so. We raise livestock \\
tihap meuli mulah tihap nukeur. Pakarang & not to buy it or have a barter with it. We \\
ulah tihap nginjeum. & have utensils not to ask for them to other \\
\hline
\end{tabular}

Such aspect of the pangimbuh ning twah from the 13:3 text above if viewed in the perspective of the personal qualities of a counselor explains 12 indicators, as follows.

1) Emet, which means little or small. This implies to appreciating the small. The counselor must be careful with regard to the situation and small changes that seem trivial around him/her. The ignorance on the small things can affect to a bigger situation, so the problem becomes difficult to overcome.

2) Imeut, which means nothing is missed or meticulous. Being Imeut will not lead to do any work hastily, but orderly, accompanied by careful planning. Therefore, the result will be optimal, so it does not require much correction, even lead to controversy.

3) Rajeun, which means diligent, creative, and innovative.

4) Leukeun, which means doing any work diligently, not being vulnerable, and keeping to make efforts.

5) Pakapradana, which means self-confident because it is supported by the ability and physical appearance in accordance with the conditions that are facing the person. In addition, bravery to take responsibility in taking the risk of what will be and have been done is included.

6) Morogol-rogol, which means highly enthusiastic, able to deal with life challenges, and not afraid of difficulties.

7) Purusa ning sa, which means having a heroic soul and daring to uphold justice and truth. With such a heroic spirit, the person has a high awareness to help.

8) Widagda, which means wise, deliberate, not rash in making decision, and balance in terms of ratio and emotion.

9) Gapitan, which means dare to sacrifice to realize the belief and aim.

10) Karawaleya, which means considerate to other people's difficulties or having qualified empathy and social awareness.

11) Cangcingan, which means agile, not sluggish and lamented.

12) Langsitan, which means skillful, and able to catch opportunity quickly.

The religious aspect, wastu siwong, and pangimbuh ning twah are theoretically linked to one another to form the character of the Rampes as illustrated in Figure 2. 


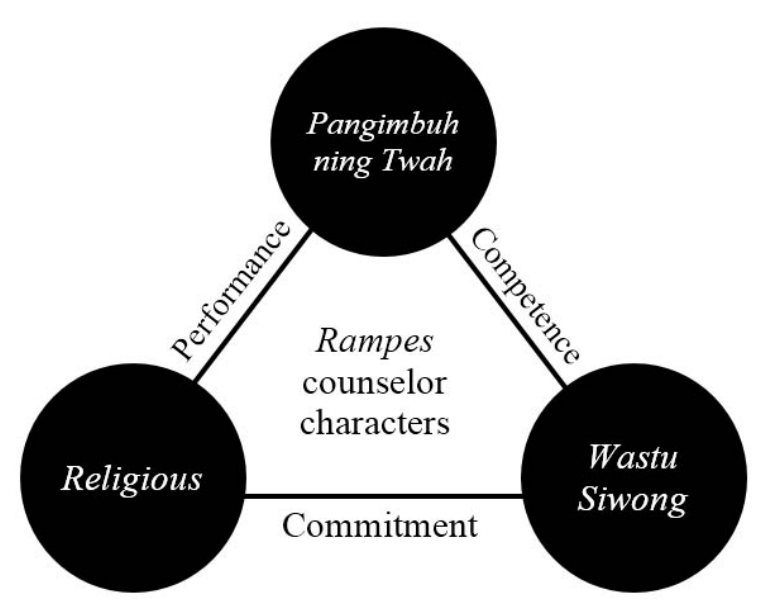

Figure 2. Scheme of Rampes counselor characters

The development of competence is also inseparable from the role of self-commitment of the individuals to improve it (Dewi, Noor, \& Alamsyah, 2015). Competence and commitment are seen as the focal factor of intellectual capital affecting the performance (Ulrich, 1998). Wastu siwong as the intellectual capital is the result of multiplication between competence and commitment. A competence formed through a combination of knowledge, skills, traits, motives, and self-conception combined with religious-based commitments will result in an intellectual capital to improve the performance of pangimbuh ning twah, leading to professional services of a professional Rampes counselor.

The study of personal characteristics of a counselor in Sanghyang Siksakandang Karesian SSK conforms to the local values (locas genius). The research findings obtained some characteristics of Rampes counselor, which were formed based on three aspects:

The first aspect, the religious personality, is the consciousness as God s creature, which will lead to a sincere spirit of devotion in helping the counselees. The second aspect, wastu siwong, represents a competent person, being able to work professionally. The third aspect, pangimbuh ning twah, is the requisites of success in family life and society. This aspect comprises 12 indicators: 1) careful, 2) thorough, 3) creative and innovative, 4) diligent and firm, 5) confident, 6) courageous, 7) patriotic/heroic, 8) wise, 9) dare to sacrifice, 10) considerate to other people's difficulties, 11) enthusiastic/not lamented, and 12) skillful/able to catch opportunities quickly.

Those personal characteristics of a counselor mentioned above are expected to promote good relationship between the counselor and the counselees in order to improve the effectiveness of guidance and counseling implementation.

\section{References}

Arifin, S., \& Zaini, A. (2014). Dakwah transformatif melalui konseling: Potret Kualitas Kepribadian Konselor Perspektif Konseling At-Tawazun. Jurnal Dakwah, 15(1), 137-156.

Bergin, A. E. (1989). Religious faith and counseling: A commentary on Worthington. The Counseling Psychologist, 174), 621-623. doi: 10.1177/0011000089174004

Cadwallader, E. H. (1991). Depression and religion: Realities, perspectives, and directions. Counseling and Values, 35(2), 83-92. doi: 10.1002/j.2161-007X.1991.tb00367.x

Cavanagh, M. E. (1982). The counseling experience: A theoretical and practical approach. California: Brooks/Cole Publishing Company.

Dahlan, M. D. (1988). Posisi bimbingan dan penyuluhan pendidikan dalam kerangka ilmu pendidikan. Pidato Pengukuhan Jabatan Guru Besar dalam Ilmu Pendidikan pada FIP IKIP Bandung, tanggal 9 April 1988.

Darajat, Z. (1993). Ilmu jiwa dan agama. Jakarta: Bulan Bintang.

Danasasmita, S., Ayatrohaedi, Wartini, T., \& Darsa, U. A. (1987). Sewaka Darma (Kropak 408), Sanghyang Siksakandang Karesian (Kropak 630), Amanat Galunggung (Kropak 632): Transkripsi dan terjemahan. Bandung: Bagian Proyek Penelitian dan Pengkajian Kebudayaan Sunda (Sundanologi) Direktorat Jenderal Kebudayaan Depdikbud. 
Dewantara, K. H. (1977). Pendidikan. Yogyakarta: Majelis Luhur Persatuan Taman Siswa.

Ekadjati, E. S. (1995). Kebudayaan Sunda: Suatu pendekatan sejarah. Jakarta: Pustaka Jaya.

Fuad, M. (2009). Kualitas Pribadi Konselor: Urgensi dan pengembangannya. KOMUNIKA, 3(2), 247-254. doi:10.24090/kom.v3i2.128

Hamzah, A. (2002). Etika sunda: Kajian isi naskah tentang pandangan hidup orang Sunda yang tercermin dalam naskah sanghyang siksa kandang karesian (tahun 1518 M). Skripsi, UIN Sunan Kalijaga Yogyakarta.

Harish, B. (2011). Influence of environment and nature on education. Journal of Education and Practice, 2(9), 13-18.

Hendrawan, L. Q. (2013). Retrieved June 2, 2017, from Makna Kata Sampurasun website https://goo.gl/Z74i6V.

Hidayat, K. (2011). Memahami bahasa agama: sebuah kajian hermeneutika. Bandung: Mizan.

Hidayat, A. (2016). Holistic vision: Integrative approach in guidance and counseling services. GUIDENA: Jurnal IImu Pendidikan, Psikologi, Bimbingan dan Konseling, 6(1), 1-10.

Huning, A. (1985) Homo mensura: human beings are their technology is human, in P. Durbin (Ed.) Research in philosophy and technology, Vol. 8 (pp. 9-16). Greenwich, CT: JAI Press.

Kartadinata, S. (2011). Menguak tabir bimbingan dan konseling sebagai upaya pedagogis. Bandung: UPI Press.

Kim, U., Yang, K. S., \& Hwang, K. K. (Eds.). (2010). Indigenous and Cultural Psychology, Helly Prajitno Soetjipto (Trans.). Yogyakarta: Pustaka Pelajar.

Lannert, J. L. (1991). Resistance and countertransference issues with spiritual and religious clients. Journal of Humanistic Psychology, 31(4), 68-76. doi: 10.1177/0022167891314005

Latif, S. (2017). Kecerdasan budaya mahasiswa calon konselor. JOMSIGN: Journal of Multicultural Studies in Guidance and Counseling, 1(1), 139-148.

Lines, D. (2006). Spirituality in counselling and psychotherapy. Sage.

Lovinger, R. J. (1984). Working with religious issues in therapy. New York and London: Jason Aronson.

Lubis, L. (2012). Landasan bimbingan dan konseling di institusi pendidikan. Journal Analytica Islamica, 1(1), 57-82.

Miller, D. W., \& Ewest, T. (2013). The Present State of Workplace Spirituality: A literature review considering context, theory, and measurement/assessment. Journal of religious \& theological information, 12(1-2), 29-54.

Meyer, M. S. (1988). Ethical principles of psychologists and religious diversity. Professional Psychology: Research and Practice, 195), 486-488.

Naqiyah, N. (2011). Pendidikan Konselor Religius. Al-Tahrir: Jurnal Pemikiran Islam, 11(2), 371-390.

Nickles, T. (2011). The role of religion and spirituality in counseling. Doctoral dissertation, California Polytechnic State University San Luis Obispo.

Novitasari, Y., \& Nur, M. (2017). Bimbingan dan konseling belajar (akademik) dalam perspektif Islam. Indonesian Journal of Educational Counseling, 1(1), 53-78.

Novitasari, Y. (2017). Kompetensi spiritual mahasiswa. JOMSIGN: Journal of Multicultural Studies in Guidance and Counseling, 1(1), 45-70.

Nurazizah, N. (2016). Etika Sunda (Studi naskah sanghyang siksakandang karesian). Skripsi, Universitas Islam Negeri Walisongo Semarang.

Nurwansah, I. (2013). Naskah lontar sunda kuna sanghyang siksakandang karesian (624): Sebuah anomali pada pernaskahan sunda kuna. JUMANTARA: Jurnal Manuskrip Nusantara, 4(1), 151-164.

Palmer, R. E. (2001). Gadamer in conversation.

Pate, R. H., \& Bondi, A. M. (1992). Religious beliefs and practice: An integral aspect of multicultural awareness. Counselor Education and Supervision, 32(2), 108-115. doi:10.1002/j.15566978.1992.tb00180.x

Patterson, M. E., \& Williams, D. R. (2002). Collecting and analyzing qualitative data: Hermeneutic principles, methods and case examples. USA: Sagamore Publishing.

Quackenbos, S., Privette, G., \& Klentz, B. (1986). Psychotherapy and religion: Rapprochement or antithesis?.Journal of Counseling \& Development,65(2), 82-85. doi:10.1002/j.15566676.1986.tb01237.x 
Rahardjo, M. (2010). Hermeneutika Gadamerian: Kuasa bahasa dalam wacana politik Gusdur. Malang: UIN Maliki Press.

Sanyata, S. (2006). Perspektif Nilai dalam Konseling: Membangun Interaksi Efektif Antara KonselorKlien. Paradigma, 1(02), 75-84.

Spink, G. S. (1963). Psychology and religion. London: Methuen \& Company Ltd.

Sumarsono, T. (2013). Retrieved May 20, 2017, from Prinsip Dasar Etika dan Jatidiri Kesundaan website https://goo.gl/R5Fd2j

Suseno, F. M. (1987). Etika dasar: Yogyakarta: Kanisius.

Ulrich, D. (1998). Intellectual capital equals competence x commitment. Sloan Management Review, 39(2), 15-26.

Wicaksono, W., \& Meiyanto, S. (2003). Ketakutan terhadap kematian ditinjau dari kebijaksanaan dan orientasi religius pada periode remaja akhir yang berstatus mahasiswa. Jurnal Psikologi, 301), 57-65. doi:10.22146/jpsi.7032

Williamson, E. G. (1958). Value orientation in counseling. Personnel \& Guidance Journal, 36, 520-528. doi:10.1002/j.2164-4918.1958.tb01107.x

Worthington Jr, E. L., Kurusu, T. A., McCollough, M. E., \& Sandage, S. J. (1996). Empirical research on religion and psychotherapeutic processes and outcomes: A 10-year review and research prospectus. Psychological Bulletin, 119(3), 448-487. doi:10.1037/0033-2909.119.3.448

Zainuri, M. (2010). Terapi keagamaan sebagai terapi penyerta bagi penyembuhan pasien penyakit dalam di rumah sakit umum (RSUP) dr. Sardjito Yogyakarta. Skripsi, UIN Sunan Kalijaga Yogyakarta. 